\title{
DOCTRINAL ISSUES OF LEGAL NATURE OF INSURANCE CONTRACT IN PREREVOLUTIONARY AND SOVIET PERIODS OF RUSSIAN LAW HISTORY
}

\author{
Marina S. Uskova \\ Volgograd Institute of Business, Volgograd, Russian Federation
}

\begin{abstract}
Introduction. Since ancient times to the present day the minds of scientists are busy with the question of determining the legal nature of the insurance contract. Some of them believe that this agreement is a type of sales contract, the contract of guarantee, etc.; another group of scientists consider the treaty as an independent and selfsufficient institution of civil law. This research work is aimed at trying to resolve the doctrinal issues and bring legal certainty to the insurance relationship. Methods. The methodological framework of this study constitutes a set of methods of scientific knowledge, among which the main place is occupied by historicist methods of systematic analysis and comparative law. Results. The author's viewpoint is based on the historical experience of scientistslawyers on the legal nature of the insurance contract, the Russian Empire, the Soviet Union and the Russian Federation legislation. As a result of analysis, the author concludes that the insurance contract is an independent civil transaction. Conclusions. As a result of the research the author highlights the main historical-scientific concepts, defending views on the legal nature of the insurance contract. It was determined that the institution of the contract of insurance is unique in its kind, has an independent legal nature and occupies a special place in the science of civil law, as well as in the Russian legislation.
\end{abstract}

Key words: history of development, insurance contract, legal nature, civil-legal transaction, Russian legislation.

УДК $347.45 / .47$

ББК 67.404 .2

\section{ДОКТРИНАЛЬНАЯ ПРОБЛЕМАТИКА \\ ОПРЕДЕЛЕНИЯ ЮРИДИЧЕСКОЙ ПРИРОДЫ ДОГОВОРА СТРАХОВАНИЯ В ДОРЕВОЛЮЦИОННЫЙ И СОВЕТСКИЙ ПЕРИОДЫ РОССИЙСКОЙ ИСТОРИИ ПРАВА}

\author{
Марина Сергеевна Ускова \\ Волгоградский институт бизнеса, Волгоград, Российская Федерация
}

\begin{abstract}
Введение: с древних времен до наших дней умы ученых занимает вопрос об определении правовой природы договора страхования: некоторые из них полагают, что данный договор является одним из видов договора купли-продажи, договора поручительства и т. д.; другая группа ученых склонна считать данный договор самостоятельным и самодостаточным институтом гражданского права. Настоящая научная работа имеет своей целью попытку разрешить данную доктринальную проблематику и внести правовую определенность в страховые правоотношения. Методы: методологическую основу данного исследования составляет совокупность методов научного познания, среди которых основное место занимают методы историзма, системности, ј анализа и сравнительно-правовой. Результаты: обоснованная в работе авторская позиция основана на историческом опыте ученых-цивилистов относительно правовой природы договора страхования, законодательстве Российской империи, СССР и Российской Федерации. В ходе анализа автор заключает, что договор страхования является самостоятельной гражданско-правовой сделкой. Выводы: в итоге проведенного исследования авто(2) ром выделены основные исторические научные концепции ученых-цивилистов, отстаивающих свои взгляды
\end{abstract}


на юридическую природу договора страхования. Определено, что институт договора страхования является уникальным в своем роде, имеет самостоятельную юридическую природу и занимает отдельное место в науке гражданского права, а также в российском законодательстве.

Ключевые слова: история развития, договор страхования, юридическая природа, гражданско-правовая сделка, российское законодательство.

\section{Введение}

С давних времен умы ученых занимает вопрос об определении юридической сути договора страхования: некоторые из них полагают, что данный договор - разновидность договора купли-продажи, договора поручительства и т. д.; другая группа ученых склонна считать данный договор самостоятельным и самодостаточным институтом гражданского права. Настоящая научная работа имеет своей целью попытку разрешить данную доктринальную проблематику и внести правовую определенность в страховые правоотношения.

Думается, что для начала следует определиться с этимологией слова «страхование».

В основе термина «страхование» лежат латинские слова «securus» (безопасный) и «sine cura» (беззаботный). От данных слов происходит «страхование» в английском языке: «insurance». Если это слово разложить, то получится словосочетание «in»+«sure» - «уверенный». Таким образом, «insure» значит «в уверенности».

В славянских языках слово «страхование» произошло от слов «страсть», «страх», «оцепенение». В сочинениях преподобного Ефрема Сирина (по списку XIV в.) находим: «Покойся, брате, не страхуй себя» [10]. Следовательно, смысл слова «страховати» - «подвергать страху, отдавать на чей-нибудь страх, то есть на чью-нибудь ответственность», иными словами, брать на свой страх и риск.

В Материалах для словаря древнерусского языка по письменным памятникам И.И. Срезневский отождествляет книжно-славянский глагол страховатися со значением «бояться, страшиться» [13, с. 545].

Традиции науки страхового права России, безусловно, базируются на истории российского права, поэтому понимание многих категорий страхового права и применение их на практике в полной мере невозможны без обращения взгляда к истокам страхования и исследо- вания научных взглядов классиков, благодаря которым сегодня стало возможным использование понятийного, статистического и исследовательского инструментария.

\section{Дореволюционный период учений о страховом договоре}

В Государстве Российском первые нормы закона регулировали морское страхование, которое появилось в 1781 г. во второй части Устава купеческого водоходства. Данные правила были заменены только в 1846 г. новым уставом. Страхование от огня было учреждено правительством в конце XVIII века. Для этих целей в 1798 г. была создана страховая контора, и уже с 1801 г. стали появляться частные торговые конторы и компании для страхования. Однако российские законы в это время не регламентировали подробно правила о страховании, только правила морского страхования были отнесены к Уставам торговым. В Своде законов гражданских есть глава о страховании, но она содержит в себе только две общих статьи и отсылает к уставам страховых компаний (ст. 2199, 2200).

Правовое направление страхования явилось предметом значительного числа научных трудов, к которым прежде всего следует отнести первую русскую диссертацию по страхованию «Договор морского страхования по русскому праву» А. Вицына (СПб., 1865). В российской научной среде дореволюционного периода истории в сфере страхования, несомненно, следует выделить профессора П.А. Никольского, выводы и мысли докторской диссертации которого «Основные вопросы страхования» до сих пор служат теоретической базой для доктринальных исследований.

Одной из наиболее дискуссионных доктринальных проблем, которая занимала умы ученых-юристов в дореволюционный период, стало определение правовой природы договора страхования. 
Так, В.П. Крюков указывал, что прежде чем приступить «...к определению юридической природы страхового договора, предварительно следует поставить на вид, что его юридическая сущность до сих пор остается точно неопределенной, почему этот вопрос пока служит предметом ученых споров, и, как видимо, еще не приведших к одному определенному результату...» [6].

Данная правовая неопределенность была связана с тем, что страховой договор не подходил ни под одни нормы существовавших в то время гражданско-правовых сделок. Так, его отождествляли как с договором купли-продажи, так и с договорами поручительства, поставки, займа и др. Но эта связь прослеживалась только внешне, и если обратиться к внутреннему содержанию страховых правоотношений, можно заключить, что страховой договор является самостоятельной сделкой.

И. Степанов в своей работе «Опыт теории страхового договора» указывает: «страховой договор есть соглашение, по которому одно лицо за известное вознаграждение обязуется устранить вместо другого лица гибель какого-либо физического предмета, если таковая произойдет в установленный срок от действия определенной разрушительной силы» [8].

На наш взгляд, указанный вариант понимания страхового договора ничем не отличается от понимания частного соглашения двух лиц, которое присуще однородным гражданско-правовым сделкам.

Думается, более точное определение дано К.П. Победоносцевым в его труде «Курс гражданского права»: «Договор страхования есть самостоятельный договор, заключается ради одного обеспечения. Одно лицо - страховщик принимает у другого - страхователя имущество на свой страх, то есть обязуется вознаградить ему вред или гибель имущества от несчастного случая» [9, с. 559].

С.Е. Лион в своем сочинении «Договор страхования по русскому праву» предлагает правовое определение договора страхования в ином виде: «Страховой договор есть юридическое соглашение, в силу которого одно лицо обязуется за известное вознаграждение возместить всякую гибель имущества, кото- рая упадет в течение условленного срока и вследствие определенного несчастного случая на другое лицо, как на собственника этого имущества» [7].

Полагаем, что это определение более точное, но оно одностороннее, поскольку учитывает только собственника застрахованного имущества, без иных заинтересованных в сохранении имущества лиц, которые могут выступать страхователями.

Наконец, А. Брандт в своей статье «О страховом от огня договоре» формулирует понятие, наиболее соответствующее законодательному понятию договора страхования, изложенному в главе 7 (ст. 2199) тома 10 Свода законов Российской империи (Свод законов гражданских): «Страхованием вообще называется договор, в силу которого одна сторона обязывается, в случае известного рода несчастья, уплатить другому лицу известную сумму, не свыше заранее определенного размера, в виде вознаграждения, за причиненные данным событием убытки, между тем как другой контрагент обязывается платить страховщику определенную сумму денег» [1].

Статьей 2199 главы 7 тома 10 Свода законов Российской Империи (Свод законов гражданских) предусмотрено, что «страхование есть договор, в силу коего составленное для предохранения от несчастных случаев общество или частное лицо приемлет на свой страх корабль, товар, дом или иное движимое или недвижимое имущество за условленную премию или плату, обязуясь удовлетворить урон, ущерб или убыток от предполагаемой опасности, произойти могущей» [11].

Данное законодательное определение также следует подвергнуть критике, поскольку оно регламентирует только так называемое имущественное страхование, но не касается страхования лиц, в связи с чем является слишком узким.

Однако все изложенные варианты понимания юридической категории договора страхования указывают лишь на его внешние признаки, которые понятны всем. Но для того чтобы доказать самостоятельность данного договора, требуется более глубокий и разносторонний подход к пониманию его внутренней сущности. 


\section{ВОПРОСЫ ЧАСТНОПРАВОВОГО РЕГУЛИРОВАНИЯ}

\section{Советский период \\ доктринального определения договора страхования}

В советскую эпоху интерес к проблематике исследования юридической природы договора страхования не иссяк. Декретом Совнаркома от 6 октября 1921 г. «О государственном имущественном страховании» была введена страховая монополия государства.

Существенный и глобальный вклад в отечественную теорию страхового права внес В.И. Серебровский, разработав детальное учение о страховом договоре в своем труде «Очерки советского страхового права» [12].

Для того чтобы отличить договор страхования от схожих с ним юридических явлений, этот ученый предложил следующие признаки, присущие любому виду страховой сделки, каждый из которых он детально обосновал: 1) самостоятельность договора, 2) двусторонний характер договора, 3) рисковый характер договоpa, 4) ограниченность ответственности страховщика, 5) срочный характер этой ответственности, 6) случайный характер события, предусмотренного договором, 7) возмездность договора, 8) цель договора, направленная к обеспечению страхователя или выгодоприобретателя от возможного вреда и недостатка, 9) заключение договора с планомерно организованным страховым предприятием. В то же время исследователь воздержался от установления общего понятия страхового договора, хотя и не отрицал, что эти признаки могут быть положены в основание единого понятия договора страхования [12].

Уделяя пристальное внимание значению страхования, В.И. Серебровский отмечал, что потребность в нем неизбежна ввиду постоянного наличия в жизни и деятельности человека риска - опасности, непредвиденной по источнику своего возникновения и неравномерной по своим последствиям.

Действовавший в период подготовки «Очерков советского страхового права» Гражданский кодекс РСФСР 1922 г. нормативно не отражал единого понятия договора страхования, тем самым подтверждая теоретические заключения В.И. Серебровского [2]. Статья 367 представляла собой симбиоз понятий двух видов договора страхования (личного и имущественного).
Все последующие отечественные кодификации гражданского законодательства (Ocновы гражданского законодательства Союза ССР и союзных республик 1961 г., ГК РСФСР 1964 г., Основы гражданского законодательства Союза ССР и республик 1991 г.) неизменно исходили лишь из объединения в одной норме двух определений договора страхования, не восприняв конструкцию выделения в самостоятельные виды договора имущественного страхования и договора личного страхования. Только в период новейшей истории российского права - в Гражданском кодексе Российской Федерации 1996 г. - законодатель выделил имущественное и личное страхование в отдельные нормы, тем самым признав их самостоятельность как институтов страхового права.

\section{Выводы}

Итак, проведенный нами анализ учений о страховом договоре, принадлежащих умам научных деятелей различных исторических эпох российского права, позволяет резюмировать, что нынешнее российское законодательство все-таки рационально воспринимает эти учения, учитывает их при совершенствовании правовых норм в сфере страхования.

Процесс исследования правовой природы договора страхования с древности до новейшего времени имеет своим результатом акцентирование внимания на перспективные научные взгляды прошлого с целью получения уникального бесценного положительного опыта в понимании сущности важнейших категорий страхового права и дальнейшем совершенствовании норм страхового права.

Изложенное в очередной раз подтверждает научную позицию о том, что институт договора страхования является уникальным в своем роде, имеет самостоятельную юридическую природу и занимает отдельное место в науке гражданского права, а также в российском законодательстве.

\section{СПИСОК ЛИТЕРАТУРЫ}

1. Брандт, А. О страховом от огня договоре / А. Брандт // Журнал гражданского и уголовного права. - 1875. - № 3. - С. 94-139. 
2. Гражданский кодекс РСФСР 1922 года // Собрание узаконений и распоряжений правительства за 1922 г. - М. : Управ. Дел. Совнарк. СССР, 1950.

3. Идельсон, В. Р. Договор страхования по русскому праву / В. Р. Идельсон. - Харьков, 1904.

4. Иншакова, А. О. Компромисс в гибком регулировании внешнеэкономических споров в сфере инновационного предпринимательства / А. О. Иншакова // Вопросы правоведения. - 2014. - № 2 (24). C. $120-131$.

5.Крюков, В. П. Исторический очерк развития страхования / В. П. Крюков. - Покровск : Книгоиздательство В. 3. Яксанова, 1915. - 144 с.

6. Крюков, В. П. Очерки по страховому праву. Систематическое изложение и критика юридических норм страхового дела / В. П. Крюков. - Саратов : Книгоиздательство В. З. Яксанова, 1925. - 156 с.

7. Лион, С. Е. Договор страхования по русскому праву / С. Е. Лион. - М. : Печатня С.П. Яковлева, 1892. - $81 \mathrm{c}$.

8. Опыт теории страхового договора / под ред. И. Степанова. - Казань : Университетская тип., 1875. $-228 \mathrm{c}$.

9. Победоносцев, К. П. Курс гражданского права. Ч. 3 / К. П. Победоносцев. - Спб. : Синодальная тип., 1896. -755 с.

10. Преподобный Ефрем Сирин. Творения. В 8 т. - М. : Русский издательский центр им. святого Василия Великого, 2014. -3374 с.

11. Свод законов Российской Империи. Т. 10. Ч. І. Законы гражданские. - Спб. : Рус. Кн. Товарищество «Деятель», 1857. - 604 с.

12. Серебровский, В. И. Очерки советского страхового права / В. И. Серебровский. - М. ; Л. : Госиздат, 1926. - $184 \mathrm{c}$.

13. Срезневский, И. И. Материалы для словаря древнерусского языка по письменным памятникам. Т. 3 [Р - Щ и дополнения А - М]. Вып. 1. PСТЕП // Труды И. И. Срезневского. - СПб. : Отдние рус. яз. и словесн. Имп. АН, 1903. - [1] с., 1684. - 272 стб., 13 с.

\section{REFERENCES}

1. Brandt A. O strakhovom ot ognya dogovore [On Insurance Contract from Fire]. Zhurnal grazhdanskogo i ugolovnogo prava, 1875, no. 3, pp. 94-139.

2. Grazhdanskiy kodeks RSFSR 1992 goda [The Civil Code of the RSFSR of 1992]. Sobranie uzakoneniy $i$ rasporyazheniy pravitelstva za $1922 \mathrm{~g}$. [The collection of legalizations and orders of the government in 1922]. Moscow, 1950.

3. Idelson V.R. Dogovor strakhovaniya po russkomu pravu [The Insurance Contract According to the Russian Law]. Kharkov, 1904.

4. Inshakova A.O. Kompromiss $v$ gibkom regulirovanii vneshneekonomicheskikh sporov v sfere innovatsionnogo predprinimatelstva [Compromise in the Flexible Regulation of Foreign Economic Disputes in the Sphere of Innovative Business]. Voprosy pravovedeniya, 2014, no. 2 (24), pp. 120-131.

5. Kryukov V.P. Istoricheskiy ocherk razvitiya strakhovaniya [Historical Sketch of the Insurance Development]. Pokrovsk, Knigoizdatelstvo V.Z. Yaksanova, 1915. 144 p.

6. Kryukov V.P. Ocherki po strakhovomu pravu. Sistematicheskoe izlozhenie i kritika yuridicheskikh norm strakhovogo dela [Essays on Insurance Law. A Systematic Exposition and Criticism of the Legal Norms of Insurance]. Saratov, Knigoizdatelstvo V.Z. Yaksanova, 1925. $156 \mathrm{p}$.

7. Lion S.E. Dogovor strakhovaniya po russkomu pravu [The Insurance Contract According to the Russian Law]. Moscow, Pechatnya S.P. Yakovleva, 1892. $81 \mathrm{p}$.

8. Stepanova I., ed. Opyt teorii strakhovogo dogovora [The Experience of the Theory of the Insurance Contract]. Kazan, Universitetskaya tip., $1875.228 \mathrm{p}$.

9. Pobedonostsev K.P. Kurs grazhdanskogo prava. T. I-III [Course of Civil Law. Vol. I-III]. Saint Petersburg, Synod Publ., 1896. 755 p.

10. Prepodobnyy Efrem Sirin. Tvoreniya. $V 8 t$. [St. Ephrem The Syrian. Creations in 8 vol.]. Moscow, Russian Publishing Center of St. Basil the Great, 2014, 3374 p.

11. Svod zakonov Rossiyskoy imperii. T. 10. Ch. I. Zakony grazhdanskie [The Laws of the Russian Empire. Vol. 10. Part I. Civil Laws]. Saint Petersburg, 1857. $604 \mathrm{p}$

12. Serebrovsky V.I. Ocherki sovetskogo strakhovogo prava [Essays on the Soviet Insurance Law]. Moscow; Leningrad, Gosizdat Publ., 1926. 184 p.

13. Sreznevsky I.I. Materialy dlya slovarya drevnerusskogo yazyka po pismennym pamyatnikam. T. 3 [Materials for the Dictionary of Old Russian Language according to Written Monuments. Vol. 3]. Trudy I.I. Sreznevskogo [Work of I. I. Sreznevsky]. Saint Petrsburg, Otd-nie rus. yaz. i slovesn. Imp. AN, 1903. [1] p., 1684, 272 clmn., 13 p. 


\section{ВОПРОСЫ ЧАСТНОПРАВОВОГО РЕГУЛИРОВАНИЯ}

\section{Information About the Author}

Marina S. Uskova, Lecturer, Department of Civil Law, Volgograd Institute of Business, Kachintsev St., 63, 400010 Volgograd, Russian Federation, advokatuskova@mail.ru.

\section{Информация об авторе}

Марина Сергеевна Ускова, преподаватель кафедры гражданского права, Волгоградский институт бизнеса, ул. Качинцев, 63, 400010 г. Волгоград, Российская Федерация, advokatuskova@mail.ru. 